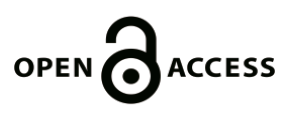

\title{
First description of the nest and nestling of White-banded Tyrannulet Mecocerculus stictopterus (Tyrannidae)
}

\author{
Harold F. Greeney*, Rudolphe A. Gelis \\ Yanayacu Biological Station \& Center for Creative Studies, km 5, vía Las Caucheras, Cosanga, Napo, Ecuador. \\ * Corresponding author, email: antpittanest@gmail.com \\ Editado por/Edited by: Diego F. Cisneros-Heredia \\ Recibido/Received: 03/11/2017. Aceptado/Accepted: 07/10/2019. \\ Publicado en línea/Published online: 31/12/2019.
}

\begin{abstract}
Resumen
Proporcionamos las primeras descripciones del nido y pichones del Tiranillo Alibandeado Mecocerculus stictopterus, apenas la segunda descripción de un nido de este género de pequeños atrapamoscas andinos (Tyrannidae). A principios de noviembre, cerca de Papallacta, noreste de Ecuador, encontramos un nido con pichones recién eclosionados. El nido era una copa abierta compuesta de líquenes y musgos, unida con telarañas y ensillada sobre una pequeña rama. El plumón natal de los pichones era bicolor, moteado, con un efecto camuflado de manchas de luz y sombra.
\end{abstract}

Palabras clave: Andes, biología reproductiva, historia natural, nido, pichón, Tiranillo Alibandeado.

\begin{abstract}
We provide the first descriptions of the nest and nestlings of White-banded Tyrannulet Mecocerculus stictopterus, only the second nest description for this genus of small Andean flycatchers (Tyrannidae). We found a single nest with newly hatched nestlings in early November, near Papallacta, northeastern Ecuador. The nest was an open cup composed of lichens and mosses, bound together with spider webs and saddled over a small branch. The natal down of the nestlings was bicolored, creating a camouflaging, sun-dappled effect.
\end{abstract}

Keywords: Andes, breeding biology, natural history.

The genus Mecocerculus includes six species of small, agile, flycatchers (Tyrannidae), five of which are found in Ecuador (del Hoyo et al., 2016). The genus is generally Andean in distribution, from Venezuela to northern Argentina, and the nest of only a single species, White-throated Tyrannulet M. leucophrys, has been described (Narosky \& Salvador, 1998).

White-banded Tyrannulet M. stictopterus is a typical member of the genus, found from western Venezuela to central Bolivia. It inhabits humid montane forests and temperate scrub near tree-line, mainly at elevations of 2300-3500 m (Ridgely \& Greenfield, 2001; del Hoyo et al., 2016). Apart from birds in breeding condition in January and August and a fledgling in December in Colombia (Hilty \& Brown, 1986), nothing has been published regarding the reproduction of $M$. stictopterus.

On the evening of 5 November 2012, RAG observed two adult $M$. stictopterus carrying insects in their bills, and discovered a nest at the Termas Papallacta hotel (-0.3618861, -78.1501001, $3315 \mathrm{~m}$ a.s.1.), c. $2 \mathrm{~km}$ north of Papallacta, Napo Province. The adults were separated from similar congeners (White-tailed Tyrannulet $M$. poecilocercus and Rufous-winged Tyrannulet M. calopterus) by the lack of white in their tails and the lack of rufous in their wings (Freile \& Restall, 2018). RAG did not examine the nest closely at that time, but noted that it contained two very small nestlings. The open cup nest was $2.4 \mathrm{~m}$ above the ground, built into an area of dense foliage in a $4.5 \mathrm{~m}$ tall tree that was growing in an isolated patch of vegetation surrounded by buildings and heavily trafficked walkways. It was supported mostly by a $1.5 \mathrm{~cm}$-diameter branch, and partially by several 
small side branches, bound to the substrate with spider webs. The nest itself was a fairly loose accumulation of lichens, mosses, liverworts, small sticks, and dark fibers, bound together with small amounts of spider webs. The external materials are a close approximation, in type and relative abundance, to naturally occurring epiphytes, making the nest extremely well camouflaged. The inner cup is composed predominantly of soft, spongey, light green Usnea sp. lichens, with a few soft, pale, flexible fibers scattered amongst the lichens. Nest measurements were: outer diameter $10.5 \mathrm{~cm}$; outer height $6.5 \mathrm{~cm}$; inner diameter $4.5 \mathrm{~cm}$; inner depth $3.5 \mathrm{~cm}$.

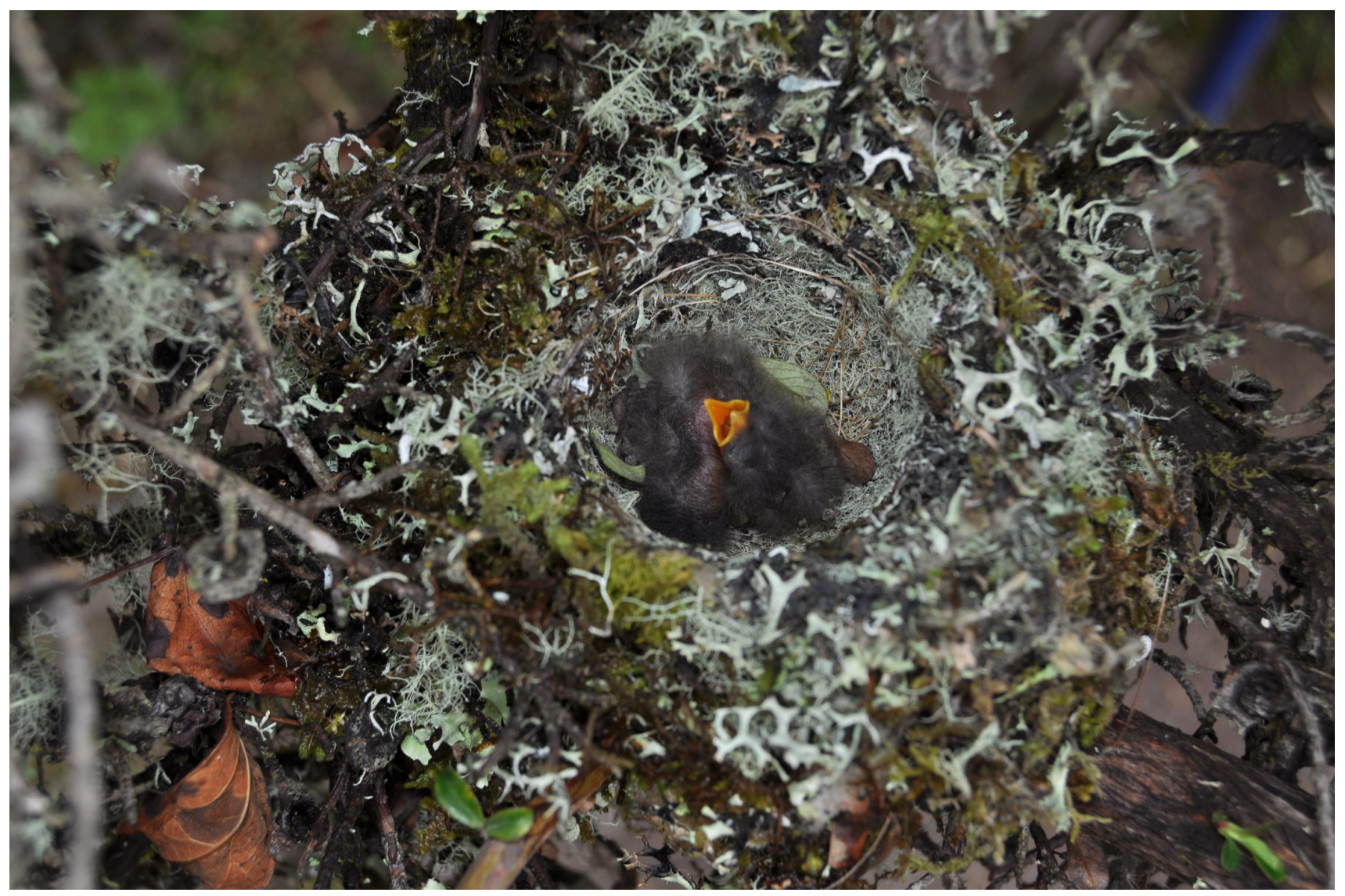

Figure 1: A nest, with two young nestlings, of White-banded Tyrannulet Mecocerculus stictopterus, 7 November 2012, Papallacta, Napo, Ecuador (H. F. Greeney).

At 9 h45 on 7 November 2012, HFG flushed an adult that was brooding the nestlings in the same nest (Fig. 2). At this time, they weighed $1.6 \mathrm{~g}$ (Fig. 3) and $2.7 \mathrm{~g}$. The nestlings had dusky orange skin, their eyes were still closed, and they were sparsely covered with natal down. The down plumes were dark grey on most of the dorsum, somewhat paler on the alar and humeral tracts. The plumes of the spinal tract were bright white at their bases, and the ventral abdominal tracts bore only short white plumes. Their feet and bills were deep orangeyellow, and the bills still bore a small white egg tooth. Their rictal flanges were slightly brighter yellow and their mouth linings were dark orange-red (Fig. 1). We again visited the nest on 16 November, at which time it still contained two nestlings (Fig. 4). The nestlings now had fairly well-developed contour feathers, and still bore most of their natal down. The bicolored down of the spinal tract created the appearance of sun-dappled shadows, presumably helping to camouflage the nestlings. At $13 \mathrm{~h} 30$ the nestlings weighed $9.8 \mathrm{~g}$ and $10.0 \mathrm{~g}$.

During our visits to the nest, adults were fairly bold, approaching the nest to feed or brood the nestlings while observers were less than $2 \mathrm{~m}$ away, in plain view. Both adults arrived at the nest carrying multiple small arthropods that included a high number of small lepidopteran larvae (especially Geometridae). Other items identified included adult crane flies (Tipulidae), spiders, and adult Lepidoptera. 
The nest of $M$. stictopterus described here closely matches the limited information available for the only congener with a described nest, M. leucophrys, including nest placement atop a horizontal branch and the use of spider webs to bind nesting material (Narosky \& Salvador, 1998). As currently defined, Mecocerculus is likely polyphyletic (Lanyon, 1988), and the relationships of its current members to other genera are uncertain (Remsen et al., 2018). As such, detailed comparisons with the nests of other genera are somewhat premature. The eggs of M. stictopterus await discovery and description.

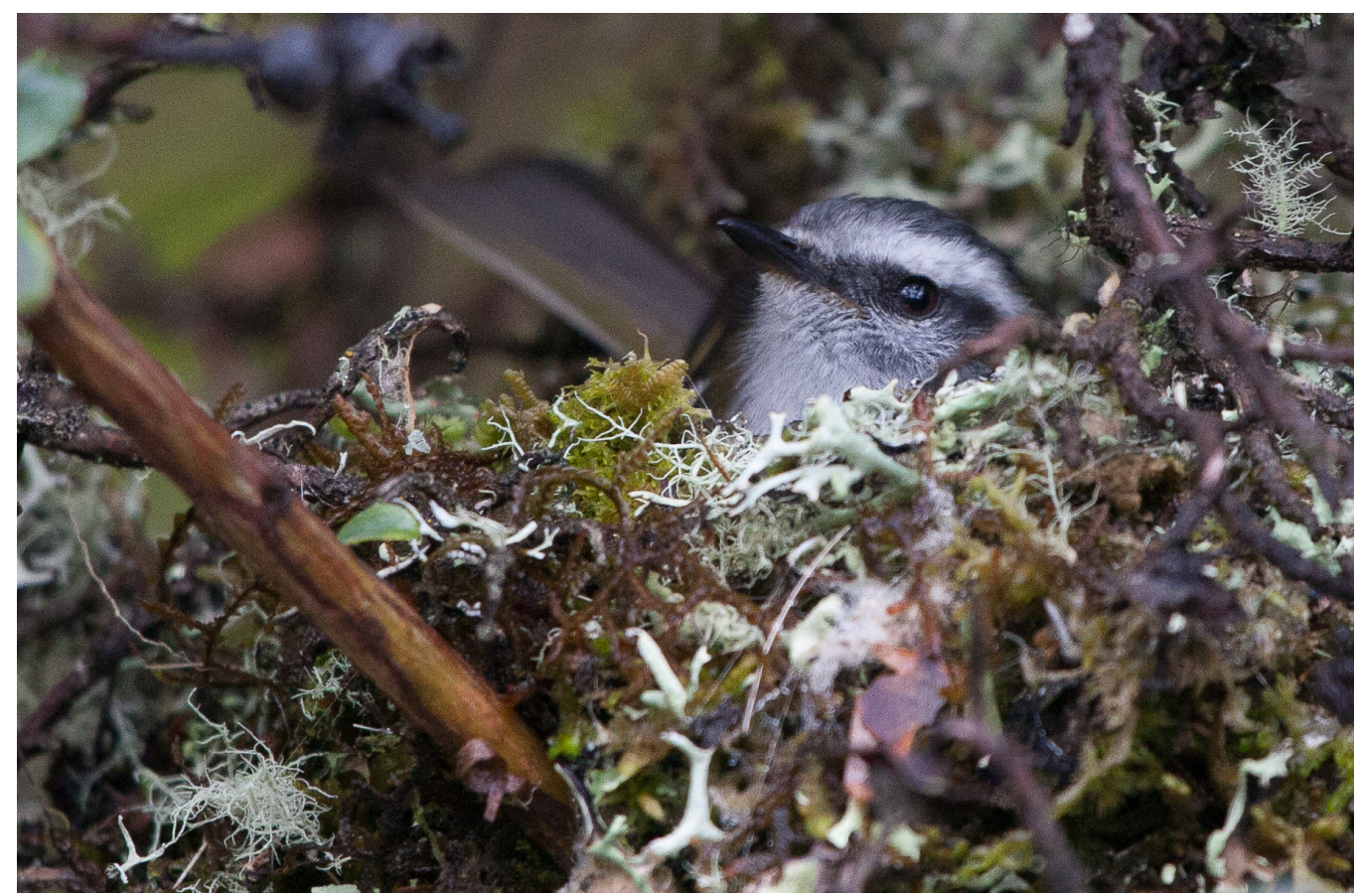

Figure 2: Adult White-banded Tyrannulet Mecocerculus stictopterus brooding two young nestlings, 7 November 2012, Papallacta, Napo, Ecuador (H. F. Greeney).

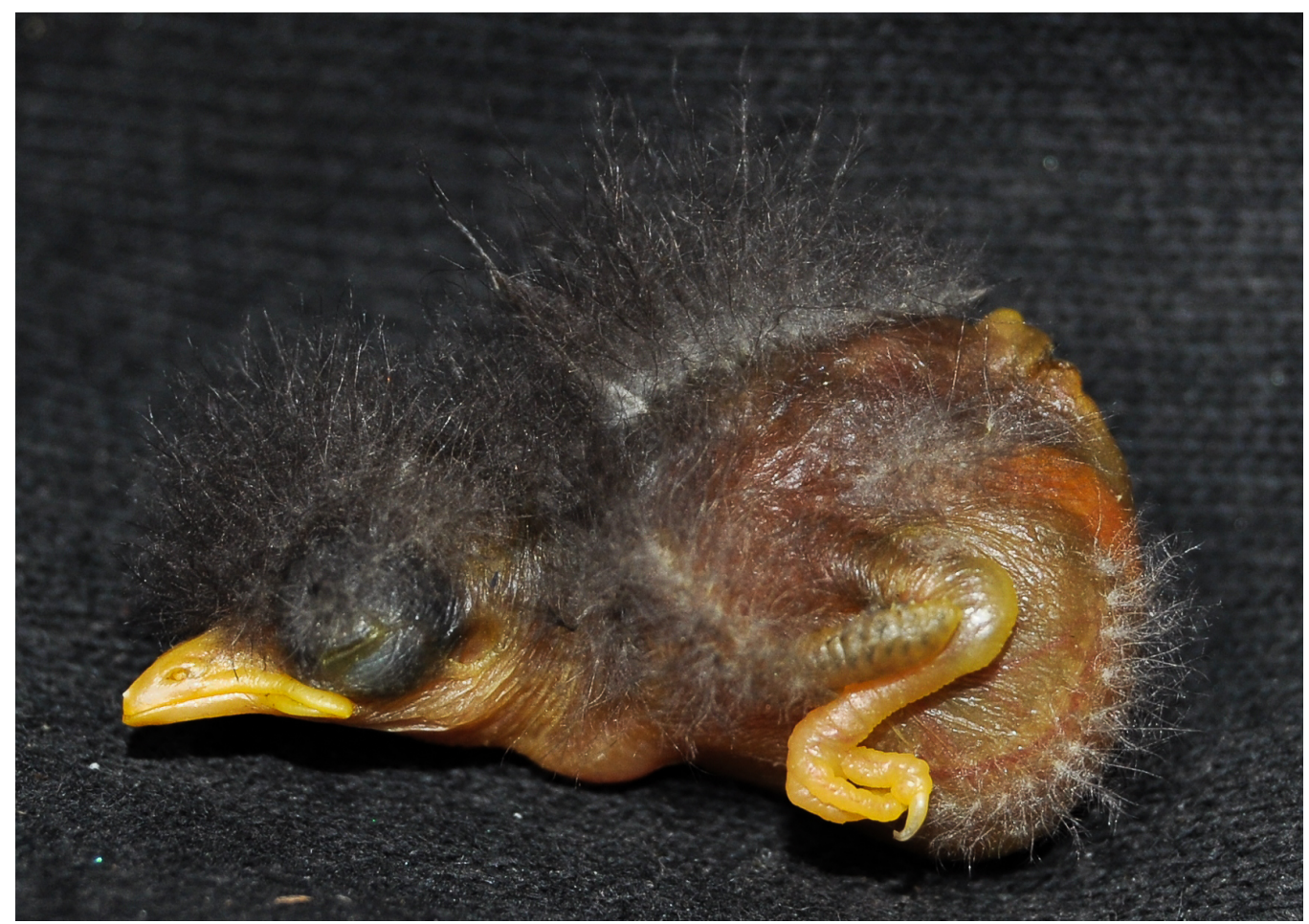

Figure 3: Young nestling (c.2 days old) of White-banded Tyrannulet Mecocerculus stictopterus, 7 November 2012, Papallacta, Napo, Ecuador (H. F. Greeney). 


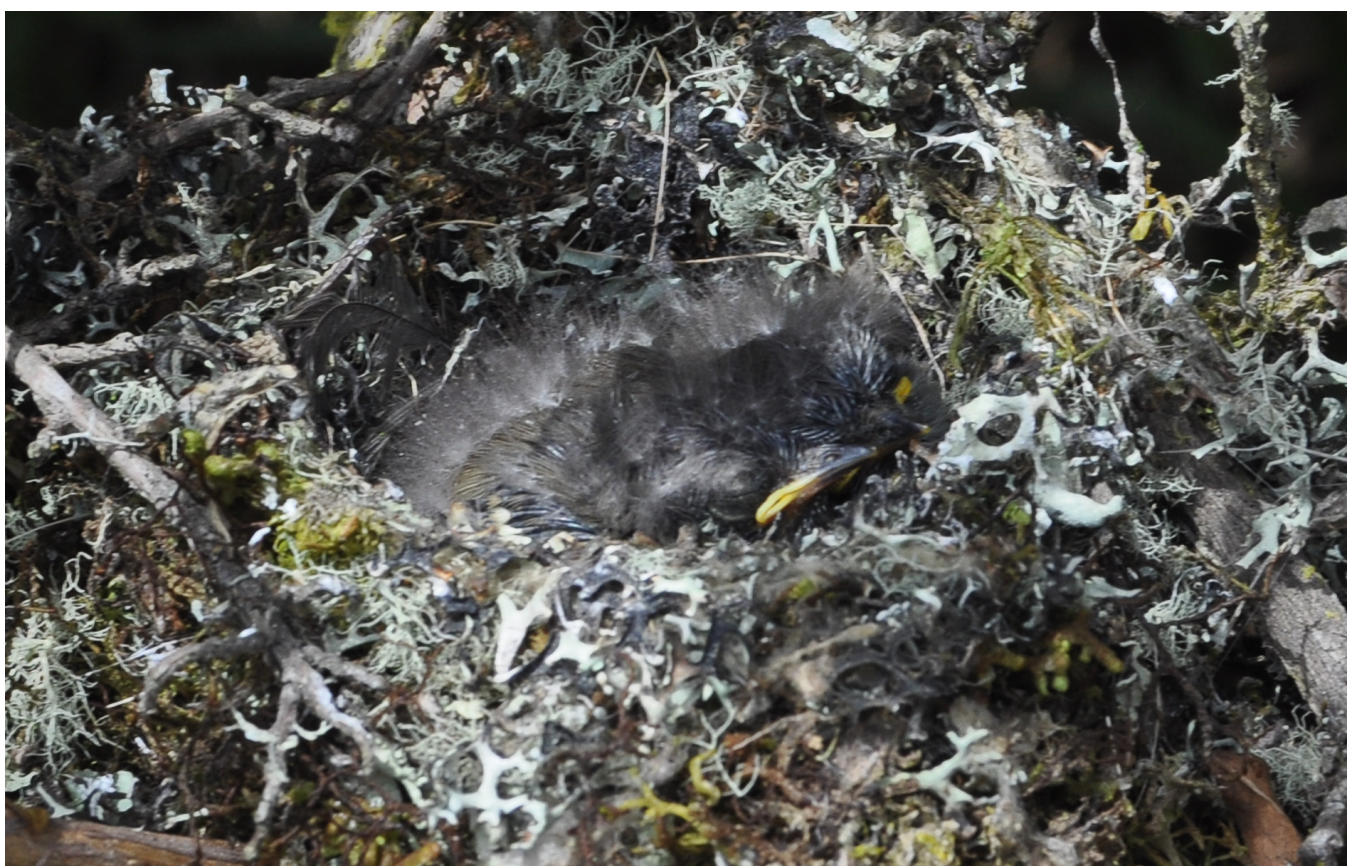

Figure 4: Mid-aged nestlings (c.11 days old) of White-banded Tyrannulet Mecocerculus stictopterus, 16 November 2012 , Papallacta, Napo, Ecuador (H. F. Greeney).

\section{ACKNOWLEDGMENTS}

We thank José Simbaña and the staff of Yanayacu Biological Station for logistical support in the field and the owners and staff of Termas Papallacta for access to their properties. HFG thanks John V. and the late Ruth Ann Moore, Matt Kaplan, and Field Guides Inc. for their support through the Population Biology Foundation. HFG was supported during the writing of this manuscript by a fellowship from the John Simon Guggenheim Memorial Foundation.

\section{REFERENCES}

Freile, J.F. \& Restall, R. (2018). Birds of Ecuador. London, UK: Christopher Helm.

Hilty, S.L. \& Brown, W.L. (1986). A guide to the birds of Colombia. Princeton, NJ: Princeton University Press.

del Hoyo, J. \& Collar, N.J. (2016). HBW and BirdLife International illustrated checklist of birds of the world, vol. 2: Passerines. Barcelona, Spain: Lynx Edicions.

Lanyon, W.E. (1988). A phylogeny of the thirty-two genera in the Elaenia assemblage of tyrant flycatchers. American Museum Novitates, 2914, 1-57. URL: http://hdl.handle.net/2246/5173

Narosky, T. \& Salvador, S. (1998). Nidificación de las aves argentinas, Tyrannidae. Buenos Aires, Argentina: Asociación Ornitológica del Plata.

Remsen, J.V., Jr., Areta, J.I., Cadena, C.D., Claramunt, A., Jaramillo, A., Pacheco, J.F., Pérez-Emán, J., Robbins, M.B., Stiles, F.G., Stotz, D.F. \& Zimmer, K.J. (2018, 30 October). A classification of the bird species of South America. American Ornithologists' Union. http://www.museum.lsu.edu/ Remsen/SACCBaseline.html

Ridgely, R.S. \& Greenfield, P.J. (2001). Birds of Ecuador. Volume 1: status, distribution, and taxonomy. Ithaca, NY: Cornell University Press. 